\title{
КОНЦЕПТУАЛЬНІ ЗАСАДИ ЛОГІСТИКИ НОВОГО ЧАСУ В СУЧАСНІЙ УКРАЇНСЬКІЙ МЕДИЦИНІ
}

\author{
${ }^{1}$ Національна медична академія післядипломної освіти імені П. Л. Шупика, м. Київ, Україна \\ 2ТОВ «Медсервісгруп», м. Київ, Україна
}

\begin{abstract}
Мета: сорормувати нову концептуальну модель логістики нового часу в сучасній українській медицині.
Матеріали і методи. Використано системний метод, метод порівняльного аналізу та прогнозування. Проаналізовано інорормаційні системи, які використовують в управлінні медичними закладами (вітчизняними і зарубіжними), та дослідження, які проводили вітчизняні та зарубіжні вчені за цією тематикою, ссрормовано концептуальні засади впровадження та використання логістики в управлінні медичними закладами.

Результати. У статті висвітлено нові концепції логістики медичних організацій в сучасних умовах. Визначено, що новий підхід до формування логістики в управлінні медичним закладом передбачає ефективність потоків пацієнтів у системі охорони здоров'я. У такій концепції сформовано чотири основні потоки медичного закладу, які визначатимуть ефективність логістичної діяльності: фрінансовий; матеріальний; людський; інформаційний (у тому числі управлінські рішення). За даних обставин медичний заклад має можливість одноразово приступити до впровадження декількох логістичних концепцій, які визначають якість надання медичних послуг, прикладом яких $є$ система інтегрованого планування ресурсів, або ERP; загальне управління якістю, або TQM; система «точно в термін», або JIT (Just In Time); точне виробництво, або LP (Lean Production); логістика, орієнтована на час, або TBL (Timebased Logistics). Розглянуто впровадження нової концептуальної моделі зрілості логістики в сучасному медичному закладі. I саме логістичні концепції (ERP, TQM, JIT, LP, TBL) є новими стратегіями у досягненні ефективності в логістичній діяльності нового часу та можуть слугувати основою для фрормування, розробки, впровадження моделі зрілості логістики в медичному закладі.

Висновки. Логістика - це управління різними вхідними та вихідними потоками медичного закладу 3 метою їх оптимізації. Відповідно, управління логістичною діяльністю в медицині виходить за рамки традиційних фрізичних потоків, враховуючи інші потоки, такі як пацієнти в ланцюгу надання медичної допомоги. Сучасним підходом до логістики медичної сорери є підхід з позицій створення цінності медичної послуги. Новий підхід до фрормування логістики в управлінні медичним закладом передбачає ефективність потоків пацієнтів у системі охорони здоров'я.
\end{abstract}

КЛЮчОВІ СЛОВА: логістика медицини; логістичні концепції; концептуальна модель зрілості; модель зрілості логістики в медицині.

Концепції та підходи до логістики в медичній сфері досліджуються багатьма науковцями: І. В. Бєлікова, А. В. Костріков [1], С. В. Борисова [2], Н. Ф. Князюк, С. А. Чеховська [3], Н. В. Котис, Р. В. Ціщик [4], М. М. Мамчин, М. М. Колядич, І. І. Фуртак [5], Н. В. Фігун, Ю. А. Дзелендзяк [6], В. П. Філіпішин [7] та інші дослідники. Незважаючи на ряд розробок, спостерігається невідповідність проблемам сорери охорони здоров'я та науковим концепціям логістичної діяльності медичних закладів. Невідповідність полягає у дослідженні логістики управління закладом із позиції класичного розуміння про складування та доставку медичних засобів та матеріалів. Тож сьогодні в медичній сорері потрібно розробляти нові концептуальні ідеї логістики, а саме логістику управління медичним закладом у таких сорерах управління: прийняття управлінських рішень, кадрова політика, організація лікувальних блоків, почерговість лікарів, безпечні умови праці, розподіл фрінансових ресурсів.
Мета дослідження: сорормувати нову концептуальну модель логістики нового часу в сучасній українській медицині.

Матеріали і методи. У статті використано системний метод, метод порівняльного аналізу та прогнозування. Зокрема, проаналізовано інфрормаційні системи, які використовують в управлінні медичними закладами (вітчизняними та зарубіжними), проаналізовано дослідження, які проводили вітчизняні та зарубіжні вчені за цією тематикою, та сорормовано концептуальні засади впровадження та використання логістики в управлінні медичними закладами.

Результати дослідження та їх обговорення. Перевагою логістичного підходу в системі охорони здоров'я $€$ можливість впливати на стратегію й тактику роботи медичної організації, на створення нових конкурентних переваг на ринку медичних послуг. Застосування логістики прискорює процес отримання та передачі інформації про необхідні ресурси, в результаті забезпечую- 
чи підвищення якості надання медичної послуги. Таким чином, логістика координує діяльність щодо ресурсного забезпечення медичної сфери в цілому.

У сучасній науковій літературі логістику в системі управління медичним закладом розглядають 3 позицій матеріально-технічного та фрармацевтичного забезпечення [4].

Логістика у системі менеджменту охорони здоров'я - це сучасний підхід до управління закладами медичної сорери, який можна розглядати 3 двох позицій - як матеріально-технічне і як фрармацевтичне забезпечення. Використання логістичних підходів дає змогу скоротити час обробки інорормації, поліпшити якісні критерії обслуговування пацієнтів, оптимізувати маршрути транспортування хворих у заклади охорони здоров'я, вирішити проблеми перенавантаження палат, а також знизити собівартість медичної послуги, розробити план своєчасної доставки ліків у необхідній кількості та належної якості, налагодити систему закупівель, постачань та зберігання медикаментів, зменшити складські площі та знизити витрати на утримання запасів [4].

Сучасним підходом до логістики медичної сорери є підхід з позицій створення цінності, що дає змогу більш ширше оцінити вклад логістичної діяльності у всіх елементах медичної сфрери. Як зазначає Н. В. Фігун [6], логістична діяльність медичного закладу безпосередньо пов'язана із ланцюгами постачань, зокрема медичної техніки, препаратів, устаткування, а також ланцюгом створення цінності, який відображатиме додану вартість кожної ланки у контексті кінцевої вартості медичної послуги.

Нову концепцію логістичної діяльності розглядає М. М. Мамчин [5]. Як зазначає науковець, уваги заслуговує логістичний підхід в організації і управлінні системою охорони здоров'я, за яким можна оптимізувати графік ресурсного забезпечення різних структурних підрозділів медичного закладу, знизити рівень запасів виробів медичного призначення з обмеженим терміном зберігання, прискорити оборотність вкладеного капіталу. Незважаючи на врахування оптимізації роботи всіх структурних підрозділів медичного закладу, все ж акцент зроблено саме на матеріальній складовій логістики.

Новий підхід до формування логістики в управлінні медичним закладом передбачає не лише традиційне забезпечення ефективності матеріально-технічних, інфрормаційних потоків, а ефрективність потоків пацієнтів у системі охорони здоров'я. Ефективність потоків можна забезпечити шляхом налагодження ефективних внутрішніх та зовнішніх логістичних процесів медичного закладу в усіх підсистемах.
Управління логістичною діяльністю в медицині виходить за рамки традиційних фрізичних потоків, враховуючи інші потоки, такі як пацієнти в ланцюгу надання медичної допомоги. Управління пацієнтами включає декілька мультидисциплінарних та взаємозалежних медичних та адміністративних заходів, які потребують контрольованого взаємозв'язку та синхронізації для уникнення проблем із часом очікування, нецільового використання медичних, фрінансових та людських ресурсів тощо [9].

Медичні заклади намагаються використовувати можливості інформаційних технологій для переходу до нового логістичного управління на основі контролю фінансових, людських, адміністративних та медичних компонентів [9]. Незважаючи на інформатизацію медичних закладів в Україні, існують системні проблеми для забезпечення ефективності процесу переходу та цифрової трансорормації медичного закладу, зокрема в сорері логістики.

Основні перешкоди для цілісного впровадження індустріалізації в системі охорони здоров'я пов'язані з бюрократизацією та управлінням на вищому рівні. Логістична культура недостатньо закріплена в стратегічному управлінні медичних закладів [12]. Крім того, ефективний логістичний підхід також залежить від кваліфікації та навичок основних суб'єктів (покупців або пацієнтів, менеджерів із логістики, медичних сестер, лікарів тощо). Медичні заклади повинні посилювати цей аспект шляхом створення інорормаційної кампанії та політики підбору персоналу та управління людськими ресурсами, адаптованої до вимог логістичної практики, визначаючи пріоритетність трьох основних складових: технологічних, організаційних та міжособистісних відносин.

Виділяють такі основні ключові галузі в медичній логістиці:

- біомедична інженерія (медична електроніка і моніторинг, медичні зображення, біоматеріали, біомеханіка);

- клінічна інженерія (гігієна, лабораторна і аналітична техніка, безпека і якість медичних технологій);

- фрармація (лікарські засоби та їх застосування);

- медичні послуги;

- персонал медичного закладу [3].

Особливе поєднання економічних, соціальних, природних фракторів в окремому регіоні визначає своєрідне співвідношення попиту і пропозиції на продукцію, цінову політику, специфіку діяльності логістичних посередників та інші регіональні особливості. Великий вплив на синтез логістичних підрозділів здійснюють регіональні транспортні комунікації, експлуатаційні підприємства транспорту, а також наявність логістичних 
посередників, стан інсрраструктури та виробничотехнічної бази регіональних систем розподілу [9].

Медицина потребує постійного вдосконалення як окремих її елементів, так і всієї системи в цілому. Логістика в медицині вимагає правильної організації всіх процесів і професійно виконаних логістичних операцій, під час виконання яких прагнення до постійного поліпшення є обов'язковою умовою для досягнення ефективності витрат, а в результаті - конкурентних переваг. Проблема застосування логістичної концепції в медичних установах тісно пов'язана з впровадженням і розвитком інноваційних технологій.

Інновації в логістиці - найактуальніша складова логістичної діяльності, покликана вивчати необхідність і можливість впровадження прогресивних інновацій в організацію поточного та стратегічного управління потоковими процесами 3 метою виявлення і використання додаткових резервів шляхом раціоналізації (оптимізації) цього управління.

3 точки зору процесів, сучасна логістика на $90 \%$ складається 3 інформаційних технологій. Тільки $10 \%$ безпосередньо становлять перевезення вантажів. Без застосування або постійної реновації інформаційних технологій в логістиці, сучасна медицина буде зазнавати великих змін у гіршу сторону, оскільки інорормаційні технології використовуються в усіх сорерах і на всіх етапах логістичного процесу [10].

Для ефективної медичної мережі, через яку відбувається потік пацієнтів (первинні медичні заклади, вторинні, третинні, лабораторії для діагностики тощо), необхідно забезпечити налагодження кадрової політики, організації лікувальних блоків, позмінну роботу лікарів, безпечні умови праці, розподіл фрінансових, людських, матеріальних ресурсів. Як наслідок, це забезпечує скорочення витрат пацієнтів та часу на лікування й надання медичних послуг. Ефрективне проходження пацієнта через налагоджений ланцюг надання медичних послуг потребує ефрективної логістики всередині медичної мережі.

Логістика - це управління різними вхідними та вихідними потоками медичного закладу з метою їх оптимізації. Якість потрібно розглядати не як набір показників у кожному окремому моменті часу та окремому підрозділі, а як безперервний потік, який необхідно розглядати як щось єдине протягом усього процесу створення медичної послуги. У такій концепції доцільно сорормувати чотири основні потоки медичного закладу, які визначатимуть ефективність логістичної діяльності:

- фрінансовий;

- матеріальний;

- людський;

- інфрормаційний (у тому числі управлінські рішення).
Розглянемо логістичну концепцію на прикладі життєвого циклу медичної послуги (рис. 1).

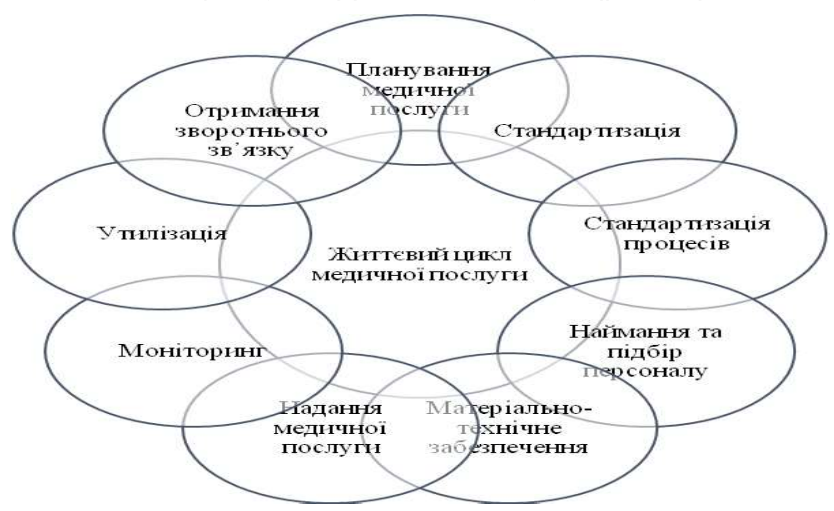

Puc. 1. Життєвий цикл медичної послуги.

Логістичні процеси наявні на всіх етапах життєвого циклу медичної послуги:

- планування медичної послуги (прогнозованих обсягів медичних послуг, зважаючи на статистику захворюваності в регіоні, області, країні; прогнозованих тарифрів на медичні послуги);

- наймання і підбір персоналу (забезпечення безпеки та умов праці, почерговість роботи, заробітної плати, потоків у кризових та звичайних умовах фрункціонування медичного закладу);

- планування та розподіл фрінансових ресурсів;

- закупівля ресурсів, обладнання та витратних матеріалів [8].

Для досягнення більшого ефректу медичні заклади можуть вдатися до впровадження інтегрованої системи логістики якості. 3 початку XXI століття, інтегрована система логістики використовується для управління основними і допоміжними потоками в різних процесах діяльності медичних закладів. У структуру діяльності повинні входити такі процеси: планування, закупівля, виробництво, розподіл, продаж, сервіс. Для оптимізації єдиної логістичної системи необхідно розглядати сукупність кількох функціональних галузей, включаючи їх учасників. За даних обставин медичний заклад має можливість одноразово приступити до впровадження декількох логістичних концепцій, які визначають якість надання медичних послуг, прикладом яких $€$ [5]:

1. Система інтегрованого планування ресурсів, або ERP (Enterprise Resource Planning). Концепція містить такі фрункції, як прогнозування попиту, управління проектами, витратами, персоналом, фінансами, тим самим дозволяючи медичному закладу повністю спланувати свою діяльність.

2. Загальне управління якістю, або TQM (Total Quality Management). Концепція об'єднує технічну сторону і фрілософрію якості. Технічна характеристика якості відображена в міжнародних стандартax ISO 9000. Філософрія полягає в повній залученості персоналу медичної організації на всіх етапах. Також TQM передбачає кооперацію з усі- 
ма контрагентами логістичної системи, особливо зі споживачами медичних послуг.

3. Система «точно в термін», або JIT (Just In Time). Система дозволяє організувати логістичні процеси таким чином, що доставка матеріально-технічних ресурсів і, відповідно, виконання медичних послуг могли здійснюватися в необхідному обсязі, в потрібному місці та в певний час. Завдяки JIT, стає можливим зниження запасів, a, отже, скорочення складських площ. Ефективне використання обладнання сприяє зниженню невиробничих операцій, скорочує терміни обстеження пацієнта в поліклініці та їх перебування в стаціонарі. Як результат, підвищується якість наданої медичної допомоги. Концепція «точно в термін» лягла в основу створення двох наступних логістичних концепцій.

3.1. Точне виробництво, або LP (Lean Production). У медичному закладі точне виробництво поєднує високу якість, низький рівень запасів, висококваліфікований персонал і «гнучке» обладнання, основний акцент зроблений на усунення непотрібних операцій (необґрунтовані повторні лабораторні тести, очікування в черзі пацієнтами). Порівняно з масовим виробництвом можна відзначити, що в даному випадку йде зниження запасів і часу, отже, зменшуються втрати від невідповідного надання медичних послуг. Але принцип «чим більші обсяги, тим нижча собівартість» зберігається.

3.2. Логістика, орієнтована на час, або TBL (Time-based Logistics). Суть концепції полягає в оптимізації часу кожного етапу життєвого циклу медичної послуги від її планування і до відстеження долі пацієнтів після надання медичної допомоги.

Окремим напрямом у діяльності медичного закладу має стати управління ризиками в логістиці якості. Ризик-орієнтований підхід дозволить своєчасно виявляти, оцінювати ризики, пов'язані з якістю та безпекою медичної діяльності, а також розробляти превентивні заходи, сорокусовані на ліквідації, мінімізації, передачі або страхуванні ризиків.

Отже, ефективність діяльності медичних закладів визначається процесами ресурсного забезпечення та передбачає:

- управління фрінансами;

- менеджмент людських ресурсів;

- управління інфрормаційними технологіями;

- управління матеріальними ресурсами.

Управління фрінансами медичних закладів передбачає:

- забезпечення потреби організацій в фрінанcax;

- бюджетування;

- ведення економічної, бухгалтерської та фрінансової звітності;
- забезпечення прийняття управлінських рішень на основі економічного аналізу господарської діяльності;

- управління фрінансовими ризиками;

- проведення аудиту та ревізій;

- аналіз економічних показників діяльності;

- зберігання фрінансових документів.

Менеджмент людських ресурсів передбачає:

- пошук, наймання, ротацію, звільнення, оцінку компетентності та розвиток персоналу;

- фрормування технологій управління, розвитку корпоративної культури;

- вдосконалення системи мотивації, забезпечення лояльності персоналу;

- навчання, інфрормування та ведення звітності з персоналу.

Компетенціями експертів у сорері логістики охорони здоров'я $є$ :

- визначення малоефективних місць і ризиків у ланцюзі постачань і розробка планів для їх усунення;

- оптимізація способів транспортування для економії коштів і часу, а також задоволення потреб клієнтів у поставках;

- забезпечення дотримання нормативних актів у всьому світі;

- розробка спеціальної упаковки для захисту чутливої медичної продукції під час перевезення;

- застосування інорормаційних технологій для ефрективного управління ресурсами, зниження кількості помилок і поліпшення обслуговування клієнтів;

- реалізація зручних рішень для дистрибуції та транспортування, які будуть відповідати умовам ринку, що постійно змінюються, включаючи піки попиту і повернення продукції [13].

Управління інформаційними технологіями включає:

- моніторинг роботи комп'ютерно-інформаційних систем (KIC), забезпечення їх функціонування;

- взаємодія з розробниками КIC;

- впровадження нового фрункціоналу КIC;

- навчання персоналу роботі з КIC;

- закупівлю, ремонт, встановлення засобів обчислювальної техніки, засобів зв'язку, програмного забезпечення.

Управління матеріальними ресурсами (господарська частина) медичних організацій:

- забезпечення поліклініки канцтоварами, меблями, технічними засобами та іншими господарськими ресурсами;

- забезпечення структурних підрозділів, кабінетів медичною апаратурою та обладнанням, витратними та господарськими ресурсами;

- ремонти і коригувальні дії щодо матеріальних активів;

- забезпечення комунальними послугами. 
Зважаючи на впровадження в медичних закладах України інформаційно-комунікаційних технологій, доцільно розглянути впровадження нової концептуальної моделі зрілості логістики в сучасному медичному закладі.

Інститут програмної інженерії розробив та запропонував модель зрілості можливостей (Сараbility Maturity Model, CMM) більше двадцяти років тому [10]. Виходячи з припущення про передбачувані закономірності еволюції та змін, моделі зрілості зазвичай включають послідовність рівнів (або етапів), які разом утворюють передбачуваний, бажаний або логічний шлях від початкового стану розвитку певних процесів в організації до зрілості [13]. Як правило, розрізняють три цілі використання моделей зрілості, що залежать від застосування [13]: описові, розпорядчі та порівняльні. Згідно з концепцією життєвого циклу організації етап зрілості характеризується досягненням однієї з лідируючих позицій на ринку. Модель зрілості слугує описовою схемою та застосовується для оцінювання поточних можливостей суб'єкта, що досліджується та оцінюється відповідно до заданих критеріїв [11]. У даному випадку модель зрілості слугуватиме інструментом та методикою вимірювання стану впровадження логістичних процесів у діяльність медичних закладів. Модель зрілості дає змогу визначити бажаний рівень зрілості та розробити заходи щодо поліпшення процесів всередині організації [11]. Мета досягається за умови проведення внутрішнього або зовнішнього бенчмаркінгу [13].

3 часу розробки моделі зрілості піддавалися критиці [13]. Охарактеризовані як «поетапні рецепти», вони надто спрощують реальність і не мають емпіричного підґрунтя. Деякі дослідники стверджують, що вони, як правило, нехтують можливим існуванням кількох однаково ефективних альтернатив вирішення проблем у певній сорері діяльності організації. Вдосконалення можуть бути здійснені в теоретичних моделях, оскільки внутрішні та зовнішні характеристики організації (наприклад, технологія, інтелектуальна власність, клієнтська база, відносини $з$ постачальниками) можуть обмежувати придатність моделі зрілості до позитивних трансорормацій організації.

Незважаючи на критику, модель зрілості з теоретичної точки зору може бути відповідним інструментом, який допоможе впровадити в медичному закладі відносно нову концепцію «Логістика 4.0» (Logistics 4.0). Основне призначення моделі зрілості в логістичній діяльності медичного закладу - описувати етапи еволюції та шляхи «дозрівання» логістичних процесів у всіх підсистемах медичного закладу. Модель зрілості в логістичній діяльності медичного закладу повинна розкривати поточний та бажаний рівень логістики, визначати відповідні заходи щодо покращення логістики.

Раніше розглянуті логістичні концепції (ERP, TQM, JIT, LP, TBL) € новими стратегіями у досягненні ефективності в логістичній діяльності нового часу та можуть слугувати основою для фрормування, розробки, впровадження моделі зрілості логістики в медичному закладі.

Для реалізації логістичної стратегії в медицині потрібна ефективна система планування, гнучкість i, що найважливіше - інорормація. Крім того, закордонний досвід вказує на те, що ефективне управління логістикою неможливе без оперативного інформаційного обслуговування, що забезпечує швидкий документообіг і створення єдиного інформаційного простору, що сприяє надійній та безперебійній роботі медичних установ, допомагає оптимізувати потік вантажоперевезень лікарських засобів і медичного обладнання в регіонах.

У свою чергу, медичному персоналу логістика допомагає повністю сконцентруватися на лікуванні та турботі про пацієнтів. Оптимізація, що забезпечує більш ефективну роботу медичного персоналу, скорочення відходів у ланцюгах поставок, надання якісних послуг та вирішення поставлених замовником завдань точно в термін $€$ пріоритетами логістики в медицині.

Таким чином, завдяки розвитку інновацій та застосування інноваційного підходу до медичної логістики, вдасться створити контрольоване й регульоване середовище для ефективного виконання різних логістичних процесів у сфері охорони здоров'я i, як наслідок, підвищити окремі показники рівня розвитку регіонів.

\section{Висновки}

Логістика - це управління різними вхідними та вихідними потоками медичного закладу з метою їх оптимізації. Відповідно, управління логістичною діяльністю в медицині виходить за рамки традиційних фрізичних потоків, враховуючи інші потоки, такі як пацієнти в ланцюгу надання медичної допомоги. Сучасним підходом до логістики медичної сорери є підхід 3 позицій створення цінності медичної послуги. Новий підхід до фрормування логістики в управлінні медичним закладом передбачає ефективність потоків пацієнтів у системі охорони здоров'я. У такій концепції сорормовано чотири основні потоки медичного закладу, які визначатимуть ефективність логістичної діяльності: фрінансовий; матеріальний; людський; інформаційний (у тому числі управлінські рішення). За даних обставин медичний заклад має можливість одноразово приступити до впровадження декількох логістичних концепцій, які визначають якість надання медичних послуг, прикладом яких є система інтегрованого планування ресурсів, або ERP; загальне управ- 
ління якістю, або ТQМ; система «точно в термін», або JIT (Just In Time); точне виробництво, або LP (Lean Production); логістика, орієнтована на час, або TBL (Time-based Logistics). У статті розглянуто впровадження нової концептуальної моделі зрілості логістики в сучасному медичному закладі. Розглянуті логістичні концепції (ERP, TQM, JIT, LP, TBL) € новими стратегіями у досягненні ефективності в логістичній діяльності нового часу та можуть слугувати основою для фрормування, розробки, впровадження моделі зрілості логістики в медичному закладі.

Перспективи подальших досліджень. Для подальших досліджень залишаються відкритими питання фрормування механізму ефективного логістичного управління медичним закладом та дослідження усіх складових логістики управління.

\section{Список літератури}

1. Бєлікова І. В. Застосування принципів логістики як основи для оптимізації інформаційно-аналітичної системи охорони здоров'я України / І. В. Бєлікова, А. В. Костріков // Вісник ВДНЗУ «Українська медична стоматологічна академія». - 2015. - Т. 15, Вип. 3 (51). - С. 81-84.

2. Борисова С. В. Разработка модели продления жизненного цикла коммерческой медицинской организации на этапе зрелости и ее апробация / С. В. Борисова // Наука Красноярья. - 2018. - Т. 7, № 1. - С. 38-58.

3. Князюк Н. Ф. Логистическая система управления качеством на примере медицинской организации / Н. Ф. Князюк, С. А. Чеховская // Бизнес-образование в экономике знаний. - 2018. - № 3. - С. 55-60.

4. Котис Н. В. Аналіз доцільності запровадження логістичного менеджменту в діяльність закладів охорони здоров'я / Н. В. Котис, Р. В. Ціщик // Економіка та управління підприємствами. - 2019. - Вип. 33. - С. 178-183.

5. Мамчин М. М. Управління системою охорони здоров'я України на сучасному етапі її рефрормування / М. М. Мамчин, М. М. Колядич, І. І. Фуртак // Вісник Національного університету «Львівська політехніка». Серія: «Проблеми економіки та управління». - 2019. - № 4. - С. 104-111.

6. Фігун Н. В. Імітаційне моделювання зовнішньої та внутрішньої логістики медичного закладу / Н. В. Фігун, Ю. А. Дзелендзяк // Вісник Національного університету «Львівська політехніка». Серія: «Логістика» : збірник наукових праць. - 2016. - № 846. - С. 171-177.

7. Філіпішин В. П. Застосування логістичних підходів у роботі лікувально-профрілактичних закладів / В. П. Філіпішин // Проблеми військової охорони здоров'я. - 2013. - № 40. - С. 84-90.

8. Ageron B. Healthcare logistics and supply chain - issues and future challenges, Supply Chain Forum / B. Ageron, S. Benzidia, M. Bourlakis // An International Journal. - 2018. - Vol. 19 (1). - P. 1-3. DOI: 10.1080/16258312.2018.1433353.

9. Becker J. Developing maturity models for IT management - a procedure model and its application / J. Becker, R. Knackstedt, J. Pöppelbuß // Business \& Information Systems Engineering (BISE). - 2009. - Vol. 1 (3). - P. $213-222$.

10. Capability maturity model for software / M. Paulk, B. Curtis, M. Chrissis, C. Weber. - 1993. Version 1.1. URL : https:// pdfs.semanticscholar.org/85f1/ef3df4f12b8d50663f96f2f41cfde99423a2.pdf

11. Investigating automation in healthcare logistics: A case study based approach / S. Benzidia, B. Ageron, B. Bentahar, J. Husson // 2nd International Conference on Project and Logistic. - 2016. - PROLOG, 5-6 May, Agadir, Morocco.

12. Pöppelbuß J. What makes a useful maturity model? / J. Pöppelbuß, M. Röglinger. - 2011. - Access mode : http://aisel. aisnet.org/ecis2011/28.

13. Sternad M. Maturity levels for Logistic 4.0 based on NRW's Industry 4.0 maturity model / M. Sternad, T. Lerher, B. Gajšek // Proceedings of The 18th International Scientific Conference Business Logistics in Modern Management. 2018, Osijek, Croatia.

\section{References}

1. Belikova, I.V., \& Kostrikov, A.V. (2015). Zastosuvannia pryntsypiv lohistyky yak osnovy dlia optymizatsii informatsiinoanalitychnoi systemy okhorony zdorovia Ukrainy [Application of the principles of logistics as a basis for optimization of the information-analytical system of health care of Ukraine]. Aktualni problemy suchasnoi medytsyny: Visnyk ukrainskoi medychnoi stomatolohichnoi akademii - Topical Problems of Modern Medicine: Bulletin of the Ukrainian Medical Dental Academy, 3 (51), 81-84 [in Ukrainian].

2. Borisova, S.V. (2018). Razrabotka modely prodleniya zhyznennogo tsykla kommercheskoy medytsynskoy organizatsii na etape zrelosti i ee aprobatsiya [Development of a model of extension of the life cycle of a commercial medical organization at the stage of maturity and its testing]. Nauka Krasnoyarya - Krasnoyarsk Science, 7 (1), 38-58 [in Russian].

3. Knyazyuk, N.F., \& Chekhovskaya, S.A. (2018). Logisticheskaya sistema upravleniya kachestvom na primere medytsynskoy organizatsii [Logistic system of quality management on the example of a medical organization]. Biznesobrazovanye v ekonomike znaniy - Business Education in the Knowledge Economy, 3, 55-60 [in Russian].

4. Kotis, N.V., \& Tsishchik, R.V. (2019). Analiz dotsilnosti zaprovadzhennia lohistychnoho menedzhmentu v diialnist zakladiv okhorony zdorovia [Analysis of the feasibility of implementing logistics management in the activities of healthcare institutions]. Ekonomika ta upravlinnia pidpriemstvamy - Economics and Enterprise Management, 33, 178-183 [in Ukrainian].

5. Mamchin, M.M., Kolyadich, M.M., \& Furtak, I.I. (2019). Upravlinnia systemoiu okhorony zdorovia Ukrainy na suchasnomu etapi yii reformuvannia [Management of the health care system of Ukraine at the present stage of its reform]. Visnyk Natsionalnoho universytetu "Lvivska politekhnika". Seriia: Problemy ekonomiky ta upravlinnia. Lviv: Vydavnytstvo Lvivskoi politekhniky - Bulletin of Lviv Polytechnic National University. Series: Problems of Economics and Management. Lviv: Lviv Polytechnic Publishing House, 4, 104-111 [in Ukrainian].

6. Figun, N.V., \& Dzelendyak, Yu.A. (2016). Imitatsiine modeliuvannia zovnishnoi ta vnutrishnoi lohistyky medychnoho zakladu [Simulation modeling of external and internal logistics of a medical institution]. Visnyk Natsionalnoho universytetu 
"Lvivska politekhnika". Seriia: Lohistyka: zbirnyk naukovykh prats - Bulletin of Lviv Polytechnic National University. Series: Logistics: A Collection of Scientific Papers, 846, 171-177 [in Ukrainian].

7. Filipishin, V.P. (2013). Zastosuvannia lohistychnykh pidkhodiv u roboti likuvalno-profilaktychnykh zakladiv [Application of logistic approaches in the work of medical establishments]. Problemy viiskovoi okhorony zdorovia - Problems of Military Health Care, 40, 84-90 [in Ukrainian].

8. Ageron, B., Benzidia, S., \& Bourlakis, M. (2018). Healthcare logistics and supply chain - issues and future challenges, Supply Chain Forum. An International Journal, 19 (1), 1-3. DOI: 10.1080/16258312.2018.1433353.

9. Becker, J., Knackstedt, R., \& Pöppelbuß, J. (2009). Developing maturity models for IT management - a procedure model and its application. Business \& Information Systems Engineering (BISE), 1(3), 213-222.

10. Paulk, M., Curtis, B., Chrissis, M., \& Weber C. (1993). Capability maturity model for software, Version 1.1. Retrieved from: https://pdfs.semanticscholar.org/85f1/ef3df4f12b8d50663f96f2f41cfde99423a2.pdf

11. Benzidia, S., Ageron, B., Bentahar, B., \& Husson, J. (2016). Investigating automation in healthcare logistics: A case study based approach. 2nd International Conference on Project and Logistic, PROLOG, 5-6 May, Agadir, Morocco.

12. Pöppelbuß, J., \& Röglinger, M. (2011). What makes a useful maturity model? Retrieved from: http://aisel.aisnet.org/ ecis2011/28.

13. Sternad, M., Lerher, T., \& Gajšek, B. (2018). Maturity levels for Logistic 4.0 based on NRW's Industry 4.0 maturity model. Proceedings of The 18th International Scientific Conference Business Logistics in Modern Management. Osijek, Croatia.

\section{CONCEPTUAL FUNDAMENTALS OF NEW LOGISTICS IN MODERN UKRAINIAN MEDICINE}

V. M. Mykhalchuk, A. V. Kolomoyets, O. K. Tolstanov, Z. V. Hbur

P. Shupyk National Medical Academy of Postgraduate Education, Kyiv, Ukraine

Medservice Group Ltd., Kyiv, Ukraine

Purpose: to form a new conceptual model of modern logistics in modern Ukrainian medicine.

Materials and Methods. The system method, the method of comparative analysis and forecasting are used. The information systems used in the management of medical institutions (domestic and foreign) and the research conducted by domestic and foreign scientists on this topic were analyzed, the conceptual principles of implementation and use of logistics in the management of medical institutions were formed.

Results. The article highlights new concepts of logistics of medical organizations in modern conditions. It is determined that a new approach to the formation of logistics in the management of a medical institution involves the efficiency of patient flows in the health care system. In this concept, four main flows of the medical institution are formed, which will determine the efficiency of logistics activities: financial; material; human; information (including management decisions). Under these circumstances, the medical institution has the opportunity to start implementing several logistics concepts that determine the quality of medical services, examples of which are: integrated resource planning system or ERP; total quality management or TQM; "In-Time" or JIT (Just In Time) system; exact production or LP (Lean Production); time-based logistics, or TBL (Time-based Logistics). The article considers the introduction of a new conceptual model of logistics maturity in a modern medical institution. The considered logistics concepts (ERP, TQM, JIT, LP, TBL) are new strategies in achieving efficiency in the logistics activities of modern times and can serve as a basis for the formation, development, implementation of a model of logistics maturity in a medical institution.

Conclusions. Logistics is the management of various inputs and outputs of a medical institution in order to optimize them. Accordingly, the management of logistics activities in medicine goes beyond traditional physical flows, taking into account other flows, such as patients in the chain of care. The modern approach to the logistics of the medical sphere is the approach from the standpoint of creating the value of medical services. A new approach to the formation of logistics in the management of a medical institution involves the efficiency of patient flows in the health care system.

KEY WORDS: logistics of medicine; logistic concepts; conceptual model of maturity; model of maturity of logistics in medicine.

Рукопис надійшов до редакції 08.07.2020 p.

\section{Відомості про авторів:}

Михальчук Василь Миколайович - доктор медичних наук, професор, заслужений працівник охорони здоров'я України, завідувач кафедри управління охороною здоров'я Національної медичної академії післядипломної освіти імені П. Л. Шупика; тел.: +38(097) 388-51-08.

Коломоєць Андрій Володимирович - кандидат медичних наук, директор ТОВ «Медсервісгруп»; тел.: +38(093) 393-07-57.

Толстанов Олександр Костянтинович - доктор медичних наук, професор, професор кафедри управління охороною здоров'я Національної медичної академії післядипломної освіти імені П. Л. Шупика;

тел.: +38(050) 313-52-81.

Гбур Зоряна Володимирівна - доктор наук з державного управління, професор кафедри управління охороною здоров'я Національної медичної академії післядипломної освіти імені П. Л. Шупика, начальник відділу магістратури; тел.: +38(050) 868-76-75. 